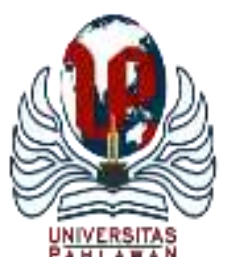

\title{
JURNALBASICEDU
}

Volume 6 Nomor 1 Tahun 2022 Halaman 1006 - 1018

Research \& Learning in Elementary Education

https://jbasic.org/index.php/basicedu

\section{Pengaruh Model Edukasi Berbasis TIK “Aplikasi Teradam” terhadap Pengetahuan Orang Tua dalam Penatalaksanaan Kegawatdaruratan Anak}

\author{
Deisy Sri Hardini ${ }^{1 凶}$, Sarwito Rachmad Barmawi ${ }^{2}$ \\ Program Studi Ilmu Keperawatan, Fakultas Ilmu Kesehatan, Universitas Muhammadiyah Purwokerto, ${ }^{1,2}$ \\ E-mail: $\underline{\text { deisysrihardini@ump.ac.id }}{ }^{1}, \underline{\text { witoito21@gmail.com }}{ }^{2}$
}

\begin{abstract}
Abstrak
Pendidikan kesehatan dengan menggunakan media tepat guna dan berbasis teknologi informasi keperawatan (TIK) dengan smartphone melalui Aplikasi Teradam (tersedak, keracunan, dan kejang demam) merupakan sebuah inovasi untuk memudahkan dan mengoptimalkan pengetahuan, pemahaman, serta praktik tatalaksana kegawatdaruratan pada anak. Desain penelitian dengan menggunakan quasi eksperimen dengan pre test post test pada dua kelompok intervensi yaitu kelompok Aplikasi Teradam dan kelompok Media Edukasi Ceramah. Sampel penelitian sebanyak 60 responden yang terdiri dari 30 responden pada kelompok Aplikasi Teradam dan 30 responden pada kelompok Media Edukasi Ceramah. Data dianalisis dengan uji paired t test dan uji T Independent. Hasil analisis paired t test menunjukkan terdapat efek signifikan dari pemberian Aplikasi Teradam dan pemberian edukasi ceramah terhadap tingkat pengetahuan orang tua dalam tatalaksana kegawatdaruratan anak $(\mathrm{p}<0,05)$. Hasil analisis uji $T$ Independent menunjukkan bahwa selisih (perbedaan) yang terjadi antar kelompok menunjukkan tidak terdapat efek yang signifikan $(\mathrm{p}>0,05)$ terhadap tingkat pengetahuan orang tua dalam tatalaksana kegawat daruratan anak. Penggunaan media edukasi ceramah dan penggunaan Aplikasi Teradam keduanya dapat diimplementasikan dalam peningkatan pengetahuan, pemahaman, dan kemampuan mempraktikkan tatalaksanan kegawatdaruratan anak, sehingga kedua media edukasi ini dapat digunakan secara bersamaan dan berdampingan.
\end{abstract}

Kata kunci: aplikasi teradam, pengetahuan, tersedak, keracunan, kejang demam

\begin{abstract}
Health education using appropriate media and based on nursing information technology (ICT) with smartphones through "The Teradam Application" (choking, poisoning, and febrile convulsions) is an innovation to facilitate and optimize knowledge, understanding, and practice of emergency management in children. The design used a quasiexperimental pre-post in two intervention groups, the Teradam Application group, and the Lecture Education Media group. The sample in this study were 60 respondents consisting of 30 respondents in the Teradam Applications group and 30 respondents in the Lecture Education Media group. The data were analyzed using paired t-test and T independent test. The results of the paired t-test analysis showed that there was a significant effect of giving the Teradam Application and giving lecture education on the level of parental knowledge in the management of child emergencies $(p<0.05)$. The results of the TIndependent test analysis showed that the differences that occurred between groups showed no significant effect ( $p>0.05)$ on the level of parental knowledge in the management of child emergencies. The use of educational media for lectures and the use of the Teradam Application can both be implemented in increasing knowledge, understanding, and ability to practice child emergency management, so that these two educational media can be used simultaneously
\end{abstract}

Keywords: Teradam Application, choking, poisoning, febrile convulsion

Copyright (c) 2022 Deisy Sri Hardini, Sarwito Rachmad Barmawi

$\triangle$ Corresponding author :

Email : deisysrihardini@ump.ac.id

DOI $\quad:$ https://doi.org/10.31004/basicedu.v6i1.2064

ISSN 2580-3735 (Media Cetak)

ISSN 2580-1147 (Media Online)

Jurnal Basicedu Vol 6 No 1 Tahun 2022

p-ISSN 2580-3735 e-ISSN 2580-1147 
1007 Pengaruh Model Edukasi Berbasis TIK “Aplikasi Teradam” terhadap Pengetahuan Orang Tua dalam Penatalaksanaan Kegawatdaruratan Anak - Deisy Sri Hardini, Sarwito Rachmad Barmawi DOI: https://doi.org/10.31004/basicedu.v6i1.2064

\section{PENDAHULUAN}

Status kesehatan anak merupakan salah satu indikator kesejahteraan bangsa, sehingga masalah kesehatan anak merupakan masalah kesehatan masyarakat dan menjadi salah satu masalah nasional. Indikator keberhasilan program kesehatan anak mengacu pada dokumen Millennium Development Goals (MDGs) 2015. Target MDGs menetapkan angka kematian bayi 23/1.000 KH, dan angka kematian balita 32/1.000 KH. Sedangkan pada RPJMN 2010-2014, target indikator angka kematian bayi 24/1.000 KH. Target-target ini merupakan agenda yang belum selesai dan masih dilanjutkan setelah tahun 2015 (post MDGs) dan pada RPJMN 2015-2019. Berdasarkan Survei Demografi Kesehatan Indonesia (SDKI) 2012, angka kematian balita masih mencapai 40/1.000 KH, angka kematian bayi 32/1.000 KH. Angka ini hanya turun 4 poin untuk kematian balita dan 2 poin untuk kematian bayi jika dibandingkan dengan angka 5 tahun sebelumnya, sedangkan angka kematian neonatal tidak mengalami penurunan (Kementerian Kesehatan RI, 2013). Angka Kematian Bayi di Kabupaten Banyumas pada tahun 2018 adalah sebesar 7,84 per 1.000 kelahiran hidup. Angka Kematian Balita adalah sebesar 8,94 per 1.000 (Dinkes Banyumas, 2020).

Cedera pada anak telah menjadi masalah kesehatan umum yang kejadiannya terus saja meningkat dan membutuhkan perhatian yang mendesak. Cedera bertanggung jawab untuk sekitar 950.000 kematian tiap tahunnya pada anak usia dibawah 18 tahun. Hampir 90\% diantaranya disebabkan karena cedera yang tidak disengaja. Sekitar 230.000 kematian terjadi pada anak usia 5-14 tahun. Setiap tahun, puluhan juta anak membutuhkan perawatan karena cedera non-fatal, bahkan banyak diantaranya mengalami cacat seumur hidup. Cedera pada anak dapat berupa cedera yang tidak disengaja (unintentional injury) dan cedera yang disengaja (intentional injury). Cedera yang tidak disengaja merupakan cedera yang bukan disebabkan oleh niat untuk menyakiti, misalnya kecelakaan lalu lintas, tenggelam, keracunan, terbakar, dan jatuh (Lubis, Pardizal, Hasanah Oswati, 2015).

Keracunan, Tersedak, dan Kejang Demam merupakan contoh dari jenis cedera yang tidak disengaja. Keracunan makanan merupakan penyakit dengan tingkat morbiditas dan mortalitas yang tinggi. Berdasarkan data CDC, tingkat mortalitas keracunan makanan mencapai sekitar 1 per 15 ribu orang sedangkan data WHO menunjukkan total angka kematian global mencapai 420 ribu per tahun. Keracunan makanan merupakan masalah global yang menimbulkan morbiditas dan mortalitas. Berdasarkan data dari Center for Disease Control (CDC) di Amerika Serikat, sekitar 76 juta orang mengalami keracunan makanan setiap tahunnya. Dari angka tersebut, 300.000 di antaranya membutuhkan rawat inap dan 5.000 kasus berakibat fatal sampai ke kematian. Data dari WHO menunjukkan bahwa 1 dari 10 orang mengalami keracunan makanan dengan angka kematian sekitar 420.000 per tahunnya. Dari angka tersebut, sekitar 30\% kematian akibat keracunan makanan terjadi pada populasi anak di bawah 5 tahun (Luthfiyani, 2021).

Pada tahun 2000-2015, terdapat 61.119 kasus keracunan makanan yang dilaporkan di Indonesia dengan tingkat mortalitas sebesar $0,4 \%$. Jenis pangan yang sering menimbulkan keracunan makanan adalah masakan rumah tangga (46,9\%), makanan jasa boga $(18,9 \%)$, dan makanan jajanan $(18,3 \%)$, sedangkan untuk patogen yang paling banyak ditemukan adalah Escherichia coli (20\%), Bacillus cereus (19,4\%), dan Staphylococcus $s p(18,3 \%)$ (Luthfiyani, 2021).

American Academy of Pediatrics (AAP) 2010, mejelaskan bahwa tersedak merupakan penyebab utama kesakitan dan kematian dikalangan anak-anak. Prevalensi tersedak pada anak usia kurang dari 1 tahun sebesar (30,5\%) tersedak pada anak usia 3 tahun kebawah sebesar (77,1\%) (Sulistiana, Adila Dian Roza, 2019).

Upaya lain yang dilakukan dalam rangka menurunkan angka kematian Balita adalah pengembangan upaya kesehatan bersumber masyarakat seperti pos pelayanan terpadu (posyandu), Penerapan PHBS dalam setiap tatanan rumah tangga, penanggulangan kurang energi protein, pendidikan gizi, penyediaan sarana air bersih dan sanitasi dasar, serta pencegahan dan pemberantasan penyakit melalui survilans dan imunisasi, serta 
1008 Pengaruh Model Edukasi Berbasis TIK “Aplikasi Teradam” terhadap Pengetahuan Orang Tua dalam Penatalaksanaan Kegawatdaruratan Anak - Deisy Sri Hardini, Sarwito Rachmad Barmawi DOI: https://doi.org/10.31004/basicedu.v6i1.2064

optimalisasi kegiatan kelas ibu balita dalam rangka upaya meningkatkan kemandirian keluarga dan masyarakat dalam merawat dan memelihara kesehatan anak.

Dalam upaya pemeliharaan kesehatan anak dan meningkatkan kemandirian keluarga dan masyarakat maka pada tahap tumbuh kembang anak usia toddler harus mendapat perhatian serius. Anak usia toddler adalah anak berusia dari 1 sampai 3,5 tahun merupakan bagian awal dari tahapan perkembangan anak setelah tahap infant. Pada tahapan usia toddler ini anak mengalami pertumbuhan dan perkembangan yang sangat pesat dimana pada masa awal tahap perkembangan ini disebut dengan golden period yaitu pada tahapan emas dimana terjadi kematangan fungsi sistem organ yang sangat pesat karena aktivasi milyaran sel-sel didalam otak tumbuh dan berkembang (Hockenberry \& David, 2015).

Tugas perkembangan anak usia toddler adalah anak sangat dominan pada keingintahuan terhadap halhal yang ada dilingkungan sekitarnya, rasa imitasi atau meniru gerakan orang yang disekitarnya lebih tinggi, dan cenderung bersikap egosentris (Hockenberry \& Wilson, 2015). Keaktifan anak dalam tahap toddler ini berisiko untuk anak mengalami kejadian seperti keracunan, tersedak, cidera, mimisan, kejang deman, dan lain lain. Orang tua diharapkan dapat mengetahui bagaimana penatalaksanaan dalam menghadapi kondisi kegawatdaruratan tersebut.

Pada penelitian tentang pemanfaatan aplikasi pediatric triage metode jumpstar mempengaruhi kesiapan penanganan awal kegawatdaruratan pada anak diperoleh hasil bahwa terdapat pengaruh kesiapan penanganan awal kegawatdaruratan pada anak dengana menggunakan uji marginal homogenity didapatkan $\mathrm{p}$ value 0.001 $<(\alpha 0.05)$ sehingga terdapat pengaruh aplikasi Paediatric Triage metode Jumpstar terhadap kesiapan penanganan awal kegawatdaruratan pada anak di SDN Purwosari 1 Kabupaten Pasuruan (Sutriningsih \& Ardiyani, 2018) .

Menurut penelitian yang berjudul Determinan Pengetahuan BHD dan Pertolongan Pertama Pada Guru Sekolah Dasar diperoleh hasil bahwa jenis mata ajar yang diampu, pengalaman pelatihan, pengalaman menolong, paparan sumber informasi, motivasi terhadap pengetahuan BHD dan pertolongan pertama menjadi faktor yang mempengaruhi pengetahuan para guru sekolah dasar dengan nilai $\mathrm{p}<0.05$. Pada hasil Analisa sumber informasi dengan pengetahuan bantuan hidup dasar dan pertolongan pertama dengan menggunakan uji Anova didapatkan sumber informasi terdiri dari paparan media, penyuluhan/pendidikan yang dipilih responden sebagai sumber informasi yang mereka gunakan untuk mencari informasi terbaru (Evelyn \& Winarti, 2019).

Selanjutnya terjadinya peningkatan nilai rerata pretest dengan kategori cukup baik (55\%) menjadi baik pada nilai posttest $(90 \%)$ dan peserta menjadi terampil dalam penanganan kasus cedera yang sering terjadi disekolah pada siswa/siswi di SMP N 9 Model Kota Lubuklinggau setelah diberikan pelatihan penanganan kasus cedera dengan menggunakan metode simulasi. Hal ini juga menunjukkan bahwa peningkatan pengetahuan juga berubah dari tingkat kurang ke tingkat cukup maupun ke tingkat baik. Hal ini sesuai dengan penelitian yang membuktikan terjadi peningkatan rerata pengetahuan dan sikap nilai pre dan post test sebelum dan sesudah pelatihan tentang pertolongan pertama (Oktaviani, E., Feri, J., 2020).

Melalui model edukasi dengan teknik penerapan komunikasi, informasi, dan edukasi (KIE) berbasis android yaitu aplikasi pada smart phone dengan pendekatan teknologi informasi keperawatan tepat guna yang diberikan kepada orang tua sangat diharapkan sebagai media pembelajaran agar orang tua lebih mudah memahami serta dapat mempraktikkan pertolongan pertama saat anak mengalami masalah kegawatdaruratan seperti kejang, tersedak, dan keracunan dengan cepat dan tepat serta dapat mempraktikkan teknik-teknik pertolongan yang tepat saat kegawatdaruratan pada anak terjadi.

Selanjutnya, dalam penelitian tentang Pengaruh Aplikasi Model "SIMBOL ANDI" terhadap pengetahuan, sikap dan keterampilan anak usia sekolah dengan risiko cedera di Kota Depok diperoleh hasil bahwa terdapat perubahan yang bermakna pada pengetahuan, sikap dan keterampilan sebelum dan sesudah diberikan intervensi $(\mathrm{p}<0.05)$ (Utami et al., 2019). 
Studi pendahuluan yang dilakukan pada tanggal 01 September 2019 kepada 10 orang tua yang memiliki anak usia toddler di Desa Sumbang, mengatakan belum pernah mendapatkan informasi dan penyuluhan kesehatan tentang pertolongan pertama saat menghadapi anak tersedak, keracunan, dan kejang demam. Selanjutnya melalui wawancara dengan petugas penanggung jawab kegiatan Posyandu Balita di Desa Sumbang disampaikan bahwa kader posyandu belum pernah mendapatkan pendidikan kesehatan tentang pertolongan pertama saat anak tersedak, keracunan, dan kejang demam, sehingga selanjutnya para kaderpun belum pernah menyampaikan informasi ini kepada orang tua.

Berdasarkan fenomena diatas maka peneliti tertarik untuk memberikan model edukasi pendidikan kesehatan kepada orang tua tentang penatalaksanaan kegawatdaruratan anak dengan menggunakan smartphone berbasis android yang berisikan materi dan vidio pembelajaran tentang pertolongan pertama saat anak tersedak, keracunan, dan kejang demam dengan aplikasi yang disingkat "Aplikasi Teradam" atau "Aplikasi Penatalaksanaan Tersedak, Keracunan, dan Kejang Demam".

Adapun tujuan penelitian ini adalah diketahuinya pengaruh model edukasi berbasis TIK "Aplikasi Teradam" terhadap pengetahuan orang tua dalam penatalaksanaan kegawatdaruratan anak di Desa Karanggintung Kecamatan Sumbang Kabupaten Banyumas.

\section{METODE PENELITIAN}

Desain Penelitian yang digunakan dalam penelitian ini menggunakan pendekatan quasi eksperiment pretest and posttest. Penelitian quasi eksperiment pretest and posttest adalah jenis penelitian dengan mengumpulkan data melalui observasi dan pengukuran sebelum diberikan perlakuan (pre intervensi) dan sesudah diberikan perlakuan (post intervensi) pada responden penelitian dengan menggunakan kelompok pembanding (Notoadmodjo, 2019). Populasi pada penelitian ini adalah orang tua yang memiliki anak balita yang bertempat tinggal di Desa Karanggintung Kecamatan Sumbang. Adapun responden yang akan digunakan dalam penelitian ini berjumlah 60 orang tua dan teknik pengambilan sampel yang digunakan adalah dengan menggunakan Purposive Sampling yaitu 30 orang tua untuk kelompok model edukasi "Aplikasi Teradam" dan 30 orang tua untuk kelompok model edukasi ceramah biasa.

Adapun kriteria inklusi dalam penelitian ini adalah orang tua yang memilki hp smart phone berbasis android dan orang tua yang bisa membaca dan menulis dan adapun kriteria eksklusi dalam penelitian ini adalah orang tua yang menolak menjadi responden dan orang tua yang tidak selesai mengisi kuesioner.

Lokasi penelitian dilakukan di Desa Sumbang Kecamatan Karanggintung Kabupaten Banyumas, dilakukan pada bulan Desember 2019 sampai Februari 2020.

Variabel bebas dalam penelitian ini adalah pemberian model edukasi yang diberikan kepada dua kelompok yaitu kelompok pertama dengan Model Edukasi Aplikasi Teradam dan kelompok kedua dengan Model Edukasi Ceramah. Adapun variabel terikat adalah pengetahuan orang tua dalam penatalaksanaan kegawatdaruratan anak.

Model Aplikasi Teradam adalah mendigitalisasikan materi kegawat daruratan pada anak saat tersedak, keracunan, dan kejang demam yang merujuk dari Buku Pedoman Kegawatdaruratan Anak yang diterbitkan oleh WHO bekerjasama dengan Kementerian Kesehatan RI dan Ikatan Dokter Anak Indonesia Tahun 2009 (WHO, 2009).

Instrumen yang digunakan untuk mengetahui tingkat pengetahuan orang tua dengan menggunakan kuesioner dengan jenis kuesioner tertutup yaitu kuesioner yang sudah disediakan jawabnnya sehingga responden tinggal memilih. Kuesioner tingkat pengetahuan terdiri dari 17 pernyataan dengan meliputi 10 pernyataan favorable dan 7 pernyataan unfavorable dengan pilihan jawaban benar dan salah. Total nilai pengetahuan dikategorikan kurang (skor 17-22), cukup (skor 23-28), dan baik (skor 29-34). 
1010 Pengaruh Model Edukasi Berbasis TIK “Aplikasi Teradam” terhadap Pengetahuan Orang Tua dalam Penatalaksanaan Kegawatdaruratan Anak - Deisy Sri Hardini, Sarwito Rachmad Barmawi DOI: https://doi.org/10.31004/basicedu.v6i1.2064

Adapun untuk prosedur pelaksanaan untuk pemberian intervensi dengan menggunakan Aplikasi Teradam adalah sebagai berikut:

1. Peneliti berkoordinasi dengan Penanggung Jawab Kegiatan Posyandu Balita di Wilayah Desa Karang Gintung terkait untuk jadual dan prosedur penelitian

2. Peneliti dan Tim bekerjasama dengan semua kader yang terlibat dengan terlebih dahulu melakukan sosialisasi dan penjelasan maksud tujuan penelitian

3. Orang tua yang datang ke Posyandu setelah melalui pelayanan 5 meja, selanjutnya dengan teknik purposive sampling (non random sampling) peneliti menetapkan orang tua yang dijadikan responden untuk kelompok intervensi dan kelompok kontrol.

4. Responden yang terpilih dalam kelompok intervensi yaitu kelompok yang mendapatkan intervensi pemberian model edukasi dengan Aplikasi Teradam selanjutnya akan dijelaskan maksud dan tujuan penelitian kepada respoden dan responden selanjutnya mengisi data di Lembar Persetujuan Responden

5. Pada tahap awal dilakukan penilaian sebelum pemberian intervensi (Pre Test) untuk menilai sejauhmana tingkat pengetahuan orang tua selama ini dalam penatalaksanaan kegawatdaruratan anak dengan membagikan lembar kuesioner tingkat pengetahuan dan responden mengisi kuesioner tersebut secara mandiri

6. Tahap selanjutnya adalah peneliti mengambil dan mengumpulkan semua lembar kuesioner yang sudah terisi dan memastikan semua data demografi dan 17 pertanyaan semua terisi oleh responden

7. Selanjutnya tahap dimana peneliti menjelaskan langkah-langkah dalam mengoperasionalkan Aplikasi Teradam di HP Smartphone masing-masing responden serta menjelaskan empat fitur menu utama untuk penatalaksanaan tersedak, keracunan dan kejang demam yang berisikan gambar dan vidio.

8. Tahap akhir adalah responden diberikan lembar kuesioner untuk menilai tingkat pengetahuan setelah sebelumnya diberikan penjelasan dalam penggunaan Aplikasi Teradam

Pengolahan data dilakukan sebagai langkah awal sebelum melakukan analisis data (Hastono, 2010) dengan empat tahapan yaitu editing data, coding data, processing data, dan cleaning data. Adapaun selanjutnya proses analisis data dilakukan adalah:

\section{Analisis Univariat}

Variabel yang dilakukan dalam analisis univariat ini adalah karakteristik orang tua yaitu usia orangtua, tingkat pendidikan, dan jenis pekerjaan, dan karateristik anak yaitu usia anak dan jenis kelamin anak, variabel tingkat pengetahuan pada tahapan pre dan tahapan post pada kelompok intervensi dan kelompok kontrol dengan menggunakan nilai rerata (mean), median, standar deviasi (SD), serta nilai minimum maksimum pada tingkat kemaknaan 95\% $(\alpha=0.00)$ serta menggunakan nilai frekuensi dan persentase.

\section{Analisis Bivariat}

Analisis bivariat yang digunakan karena dari hasil uji normalitas untuk variabel Tingkat Pengetahuan dan Tingkat Pengetahuan keduanya berdistribusi normal, sehingga putusan uji yang digunakan adalah dengan Paired Test untuk menilai rerata nilai Pre dan Post dalam masing-masing kelompok intervensi dan kelompok kontrol. Selanjutnya untuk mengetahui perbedaan rerata variabel antar kelompok dengan menggunakan $U j i T$ Independen.

\section{HASIL DAN PEMBAHASAN}

\section{HASIL}

\section{Karakteristik Responden}

Karakteristik responden dalam penelitian ini terdiri dari lima variabel dan selanjutnya dideskripsikan berdasarkan jenis datanya yaitu data numerik dan data kategorik. Variabel karakteristik responden merupakan data numerik terdiri dari usia orang tua, usia anak, yang disajikan dengan menggunakan nilai rerata, standar 
1011 Pengaruh Model Edukasi Berbasis TIK “Aplikasi Teradam” terhadap Pengetahuan Orang Tua dalam Penatalaksanaan Kegawatdaruratan Anak - Deisy Sri Hardini, Sarwito Rachmad Barmawi DOI: https://doi.org/10.31004/basicedu.v6i1.2064

deviasi (SD) dan nilai minimum serta nilai maksimum, serta dan juga disajikan dalam bentuk kelompok umur orang tua dan kelompok umur anak yang disajikan dalam bentuk frekuensi dan persentase. Adapun variabel jenis kelamin anak, jenis pekerjaan, tingkat pendidikan, merupakan data kategorik dan disajikan dalam frekuensi dan persentase.

Rerata distribusi responden berdasarkan usia orang tua yaitu 32,97, dengan usia minimum 25 tahun dan usia maksimum 40 tahun dan rerata usia anak adalah 31,45 bulan dengan usia minimum 12 bulan dan usia maksimum 50 bulan.

Tabel 1 Distribusi Responden Berdasarkan Usia Orang Tua dan Usia Anak (n=60)

\begin{tabular}{llll}
\hline Variabel & \multicolumn{1}{c}{ Rerata } & SD & Min-Maks \\
\hline & & & \\
\hline Usia Orang Tua & 32,97 (tahun) & 2,774 & $25-40$ \\
\hline Usia Anak & 31,45 (bulan) & 10,280 & $12-50$ \\
\hline
\end{tabular}

Karakteristik respoden berdasarkan kelompok usia anak, usia terbanyak pada kelompok usia 12-36 bulan sebesar 40 anak $(66,7 \%)$ dan untuk kelompok usia orang tua, usia terbanyak berada pada rentang usia lebih dari 30 tahun $(81,7 \%)$. Selanjutnya berdasarkan jenis kelamin anak terbanyak adalah perempuan sebanyak 41 anak (68,3\%), untuk orang tua semuanya berjenis kelamin perempun yaitu $60 \mathrm{Ibu}(100 \%)$, untuk data tingkat pendidikan orang tua sebesar 25 orang tua $(41,7 \%)$ dengan tingkat pendidikan SD, dan pekerjaan orang tua sebagian besar yaitu sebanyak 45 orang tua (75\%) orang tua tidak bekerja atau ibu rumah tangga.

Tabel 2 Distribusi Responden Berdasarkan Kelompok Usia Anak, Kelompok Usia Orang Tua, Jenis Kelamin Anak, Jenis Kelamin Orang Tua, Tingkat Pendidikan Orang Tua, Pekerjaan Orang Tua $(\mathbf{n}=60)$

$\begin{array}{lll}\text { Variabel } & \text { Frekuensi } & \text { Persentase }(\%)\end{array}$

\begin{tabular}{lcc}
\hline Kelompok Usia Anak & 2 & \\
\hline$<12$ Bulan & 40 & 3.3 \\
\hline 12-36 Bulan & 18 & 66.7 \\
\hline$>36$ Bulan & 11 & 30 \\
\hline Kelompok Usia Orang Tua & 49 & 18.3 \\
\hline 20-30 Tahun & & 81.7 \\
\hline $\begin{array}{l}\text { >30 Tahun } \\
\text { Jenis Kelamin Anak }\end{array}$ & 41 & 68,3 \\
\hline Perempuan & 19 & 31,7 \\
\hline Laki-laki & 60 & 100 \\
\hline Jenis Kelamin Orang Tua & & \\
\hline Perempuan & 25 & 41,7 \\
\hline Tingkat Pendidikan Orang Tua & 18 & 30.0 \\
\hline SD & 12 & 20,0 \\
\hline SLTP & 5 & 8,3 \\
\hline SLTA & & 25 \\
\hline Perguruan Tinggi & 15 & 75 \\
\hline Pekerjaan Orang Tua & 45 & \\
\hline Bekerja & & \\
\hline Tidak Bekerja & & \\
\hline
\end{tabular}


1012 Pengaruh Model Edukasi Berbasis TIK “Aplikasi Teradam” terhadap Pengetahuan Orang Tua dalam Penatalaksanaan Kegawatdaruratan Anak - Deisy Sri Hardini, Sarwito Rachmad Barmawi DOI: https://doi.org/10.31004/basicedu.v6i1.2064

Untuk data tingkat pengetahuan orang tua dalam penatalaksanaan kegawatdaruratan anak setelah diberikan intervensi menunjukkan 33 orang tua dengan kategori tingkat pengetahuan baik (55\%).

Tabel 3 Tingkat Pengetahuan Orang Tua Sesuadah Pemberian Intervensi Dalam Penatalaksanaan Kegawatdaruratan Anak $(n=60)$

\begin{tabular}{|c|c|c|}
\hline Variabel & Frekuensi & Persentase $(\%)$ \\
\hline \multicolumn{3}{|c|}{ Tingkat Pengetahuan Orang Tua (post) } \\
\hline Kurang & 13 & 21,7 \\
\hline Cukup & 14 & 23,3 \\
\hline Baik & 33 & 55,0 \\
\hline Total & 60 & 100 \\
\hline
\end{tabular}

Sebelum keputusan uji statistik bivariat dilakukan, maka sebelumnya dilakukan Uji Normalitas Data. Uji normalitas data dilakukan dengan menghitung nilai Skewness dibagi dengan nilai Standar Error, jika hasil kurang dari 2 maka data berdistribusi normal(Riyanto, 2019). Hasil pembagian Skewness dan Standar Error untuk data Tingkat Pengetahuan Pre dengan nilai 0.51 (kurang dari 2) dan Tingkat Pengetahuan Post dengan nilai 0.54 (kurang dari 2) sehingga kedua data berdistribusi normal. Selanjutnya keputusan uji statistik yang digunakan untuk data berdistribusi normal adalah dengan menggunakan Uji Parametrik.

Analisis bivariat yang dilakukan dalam penelitian ini adalah untuk mengetahui tingkat pengetahuan orang tua dalam penatalaksanaan kegawat daruratan anak pada tahap sebelum (pre intervensi) dan tahap sesudah (post intervensi) dalam masing-masing kelompok dengan menggunakan uji statistik paired t test.

Analisis bivariat selanjutnya yang juga dilakukan dalam penelitian ini adalah dengan uji statistik Independent T-Test untuk mengetahui perbedaan rerata variable tingkat pengetahuan pada kelompok yang diberikan media edukasi melalui Aplikasi Teradam dan kelompok yang diberikan media edukasi melalui ceramah.

\section{Perbandingan Rerata Nilai Tingkat Pengetahuan pada Tahap Sebelum (Pre) dan Tahap Sesudah (Post) dalam Masing-Masing Kelompok.}

Perbandingan nilai tingkat pengetahuan pada tahap sebelum (pre) dan tahap sesudah (post) dalam masing-masing kelompok yaitu dalam kelompok Aplikasi Teradam dan kelompok Media Edukasi dengan menggunakan uji statistik paired t test. Rerata nilai tingkat pengetahuan pada kelompok dengan Aplikasi Teradam sebelum perlakuan diberikan adalah 25.37, pada tahap sesudah perlakuan menjadi 27.93. Berdasarkan hasil analisis statistik diketahui bahwa perbedaan rerata nilai tingkat pengetahuan yang terjadi antara tahap sebelum dan sesudah pemberian intervensi pada kelompok dengan Aplikasi Teradam terdapat perbedaan yang bermakna yaitu $\mathrm{p}$ value $0.000(\mathrm{p}<0.05)$.

Pada kelompok dengan pemberian media edukasi melalui ceramah, diketahui bahwa rerata nilai tingkat pengetahuan sebelum pemberian intervensi adalah 26.13, pada tahap sesudah pemberian intervensi yaitu menjadi 28.73. Hasil analisis statistik menunjukkan bahwa terdapat perbedaan bermakna rerata nilai tingkat pengetahuan antara tahap sebelum dan tahap sesudah pemberian edukasi dengan media ceramah yaitu $\mathrm{p}$ value $0.000(\mathrm{p}<0.05)$. 
1013 Pengaruh Model Edukasi Berbasis TIK “Aplikasi Teradam” terhadap Pengetahuan Orang Tua dalam Penatalaksanaan Kegawatdaruratan Anak - Deisy Sri Hardini, Sarwito Rachmad Barmawi DOI: https://doi.org/10.31004/basicedu.v6i1.2064

Tabel 4 Perbandingan Rerata Tingkat Pengetahuan Responden Tahap Sebelum dan Tahap Sesudah dalam Masing-Masing Kelompok (n=60)

\begin{tabular}{|c|c|c|c|c|c|c|c|c|}
\hline \multirow{2}{*}{ Kelompok } & \multirow[t]{2}{*}{ Mean } & \multirow[t]{2}{*}{ SD } & \multirow[t]{2}{*}{ SE Mean } & \multicolumn{2}{|c|}{$\begin{array}{c}\text { MD } \\
(95 \% \mathrm{CI}) \\
\end{array}$} & \multirow[t]{2}{*}{$\mathbf{t}$} & \multirow[t]{2}{*}{$d f$} & \multirow[t]{2}{*}{$p$} \\
\hline & & & & Lower & Upper & & & \\
\hline Aplikasi Teradam & & & & $-3,054$ & $-2,079$ & $-10,775$ & 29 & 0,000 \\
\hline Sebelum (pre) & 25,37 & 4,460 & 0,814 & & & & & \\
\hline Sesudah (post) & 27,93 & 3,886 & 0,709 & & & & & \\
\hline \multicolumn{9}{|c|}{ Media Edukasi Ceramah } \\
\hline Sebelum (pre) & 26,13 & 5,184 & 0,947 & \multirow{2}{*}{$-3,318$} & \multirow{2}{*}{$-1,882$} & \multirow{2}{*}{$-7,407$} & \multirow{2}{*}{29} & \multirow{2}{*}{0,000} \\
\hline Sesudah (post) & 28,73 & 3,973 & 0,725 & & & & & \\
\hline
\end{tabular}

Perbandingan Rerata Nilai Tingkat Pengetahuan pada Tahap Sebelum (Pre) dan Tahap Sesudah (Post) Pada Tiap Kelompok Intervensi.

Perbandingan nilai tingkat pengetahuan pada tahap sebelum (pre) dan tahap sesudah (post) pada dua kelompok yaitu antar kelompok Aplikasi Teradam dan kelompok Media Edukasi Ceramah dengan menggunakan uji statistic T Test Independent. Adapun hasil tingkat pengetahuan sebelum diberikan intervensi dengan metode ceramah dan aplikasi teradam menunjukkan hasil yang tidak bermakna dengan nilai $\mathrm{p}$ value 0.542 ( $\mathrm{p}$ value $>0.00$ ). Selanjutnya untuk tingkat pengetahuan sesudah diberikan intervensi dengan metode ceramah dan aplikasi teradam juga menunjukkan hasil yang tidak bermakna dengan nilai $\mathrm{p}$ value 0.434 ( $\mathrm{p}$ value $>0.00)$.

Tabel 5 Perbandingan Rerata Tingkat Pengetahuan Responden Tahap Sebelum dan Tahap Sesudah Antar Kelompok Intervensi $(\mathbf{n}=60)$

\begin{tabular}{|c|c|c|c|c|c|c|c|}
\hline Kelompok & Mean & SD & $\underset{\text { Mean }}{\text { SE }}$ & $\begin{array}{c}\text { Mean } \\
\text { Differ } \\
\text { ence }\end{array}$ & $\mathbf{t}$ & $d f$ & $p$ \\
\hline \multicolumn{4}{|c|}{ Tingkat Pengetahuan (Pre) } & & & & \\
\hline $\begin{array}{l}\text { Metode } \\
\text { Ceramah }\end{array}$ & 26,13 & 5,184 & 0,947 & 0,767 & 0,614 & 58 & 0,542 \\
\hline $\begin{array}{l}\text { Aplikasi } \\
\text { Teradam }\end{array}$ & 25,37 & 4,460 & 0,814 & & & & \\
\hline
\end{tabular}

\begin{tabular}{|c|c|c|c|c|c|c|}
\hline \multicolumn{7}{|c|}{ Tingkat Pengetahuan (Post) } \\
\hline $\begin{array}{l}\text { Metode } \\
\text { Ceramah }\end{array}$ & 28,73 & 3,973 & $\begin{array}{l}0,725 \\
\end{array}$ & 0.788 & 58 & 0.434 \\
\hline $\begin{array}{l}\text { Aplikasi } \\
\text { Teradam }\end{array}$ & 27,93 & 3,886 & 0,709 & & & \\
\hline
\end{tabular}


1014 Pengaruh Model Edukasi Berbasis TIK “Aplikasi Teradam” terhadap Pengetahuan Orang Tua dalam Penatalaksanaan Kegawatdaruratan Anak - Deisy Sri Hardini, Sarwito Rachmad Barmawi DOI: https://doi.org/10.31004/basicedu.v6i1.2064

PEMBAHASAN

\section{Karakteristik Responden}

Karakteristik Orang Tua dalam penelitian ini terlihat bahwa semua orang tua yang berperan dalam membawa anaknya kekunjungan Posyandu adalah Ibu-ibu, hal ini disebabkan bahwa mayoritas Kepala Keluarga yaitu Bapak yang dominan untuk bekerja mencari nafkah diluar sehingga Ibulah yang berperan untuk mengasuh anaknya dirumah. Pembagian peran dan tanggung jawab dalam rumah tangga ini sesuai dengan fungsi keluarga yaitu salah satunya adalah fungsi ekonomi. Fungsi ekonomi yang dimaksud ialah pembagian tugas seperti ayah yang mencari nafkah dan ibu yang mengurus rumah tangga (Marenda, 2019).

Dengan rentang usia response orang tua yaitu $>30$ tahun menunjukkan bahwa usia ini adalah usia masuk dalam tahapan masa dewasa akhir. Pada masa ini, manusia menghabiskan sebagian besar masa hidupnya berada di tahap kedewasaan, lebih dari tahap perkembangan lainnya dalam siklus hidup. Karena itu perubahan kognitif banyak terjadi pada tahap kedewasaan. Beberapa penelitian menemukan bahwa perkembangan kognitif pada orang dewasa lebih kompleks dan selalu berubah, bahkan mungkin lebih aktif dari pada perkembangan kognitif pada masa balita dan usia dini (Retno, 2018). Tidak seperti perkembangan fisik yang memuncak di usia 20 tahunan dan mulai menurun secara perlahan, kemampuan kognitif kita tetap stabil dimasa dewasa awal dan dewasa tengah. Menurut penelitian lain, bahwa orang dewasa yang terlibat banyak aktivitas yang menstimulasi secara fisik dan mental akan mengalami lebih sedikit risiko penurunan kognitif pada tahapan usia dewasa selanjutnya dan memiliki risiko yang berkurang akan mengalami masalah kognitif demensia.

Tingkat pendidikan orang tua sebagian besar dengan tingkat pendidikan SD sehingga sebagian besar Ibu tidak bekerja atau Ibu Rumah Tangga. Tingkat pendidikan yang rendah bukanlah faktor yang menghambat seseorang untuk bisa mendapatkan berbagai sumber informasi diera digital seperti ini. Orang tua sangat dengan memudah mengakses berbagai macam informasi. Mudahnya orangtua dalam mengakses informasi harus berbanding lurus kemampuan orang tua untuk dapat menyaring sumber-sumber pemberi informasi yang valid dan akurat.

Dimasa sekarang ini, pemahaman yang luas tentang teknologi sangat dibutuhkan orang tua agar dapat mendampingi anak-anak yang sejak lahir pun sudah bersentuhan dengan teknologi. Hal ini menjadi penting karena kemajuan teknologi dan kemudahan berkomunikasi, serta mengakses segala informasi jika tidak dibarengi oleh kedewasaan berpikir dapat menjadi masalah, terutama untuk tumbuh kembang anak. Selain itu, orangtua yang melek teknologi dapat membantu mengurangi jarak atau kesenjangan antara orang tua dan anak (Ulya, 2019).

Anak masa kini memiliki pemahaman yang luas tentang teknologi. Yang dapat dilakukan orang tua agar sama "melek media"nya dengan anak diantaranya adalah bahwa teknologi digital dapat menghadirkan banyak hal positif dalam belajar, menawarkan kegiatan menantang, dan kesempatan untuk belajar menyelesaikan masalah sehari-hari.

Karaktersitik anak dalam penelitian ini terlihat bahwa usia anak berada dalam kelompok umur terbesar berada pada rentang > 12 sampai 36 bulan atau dalam tahapan usia toddler. Usia toddler adalah tahap usia anak mulai dari usia 18 bulan sampai usia 36 bulan, dimana tugas perkembangan anak pada usia toddler ini adalah lebih dominan pada perkembangan motorik kasar. Anak menunjukkan kemampuan aktivitas yang lebih banyak bergerak, mengembangkan rasa ingin tahu dan eksplorasi terhadap benda-benda yang ada disekelilingnya. Keterampilan motorik seperti berlari, berjalan, melompat menjadi sangat luwes, tetapi otot dan tulang belum begitu sempurna, sehingga karakteristik perkembangan anak usis toddler lebih berisiko terjadi kecelakaan(Hockenberry, M.J., 2014). 
1015 Pengaruh Model Edukasi Berbasis TIK “Aplikasi Teradam” terhadap Pengetahuan Orang Tua dalam Penatalaksanaan Kegawatdaruratan Anak - Deisy Sri Hardini, Sarwito Rachmad Barmawi DOI: https://doi.org/10.31004/basicedu.v6i1.2064

\section{Tingkat Pengetahuan Orang Tua Sesuadah Pemberian Intervensi Dalam Penatalaksanaan Kegawatdaruratan Anak}

Kemajuan teknologi yang begitu pesat telah memberikan kemudahan bagi masyarakat dalam menjalankan aktivitas kesehariannya terutama dalam mengakses informasi dengan cepat. Kemajuan teknologi juga memberikan pengaruh signifikan terhadap kehidupan masyarakat termasuk dalam ruang lingkup keluarga. Tentunya kemajuan teknologi tersebut harus disikapi secara bijak dan tepat agar memberikan kebermanfaatan bagi keluarga terutama dalam merawat anak. Salah satunya melalui berbagai vitur smartphone yang memberikan kemudahan akses berbagai informasi (Firken, 2016). Aplikasi Teradam diciptakan salah satunya adalah menjawab kebutuhan orang tua seputar informasi dan edukasi yang berisi pengetahuan, gambar, dam vidio tentang bagaimana tatalaksana yang dapat dilakukan oleh orang tua saat menghadapi kondisi gawat darurat pada anak tersedak, keracunan, dan kejang demam.

Kecelakaan pada balita ternyata menurut penelitian paling sering terjadi di rumah. Terutama jika barang-barang atau kondisi dirumah tidak ramah anak, ditambah lagi pengawasan yang kurang. Kecelakaan dan insiden memang bisa terjadi pada siapapun, terutama pada balita. Balita dalam tugas fase oralnya yaitu senang sekali memasukkan apapun ke mulutnya. Orang tua harus waspada dan memastikan mainan yang anak mainkan adalah aman, ukurannya tidak terlalu kecil yang sangat berisiko membuat tertelan. Begitu juga untuk makanan, orang tua harus selalu mengawasi anak saat ia belajar makan makanan padat atau sayuran kukus dikarenakan anak belum bisa mengunyah dan tersedak ketika potongan makanan terlalu besar (Dream, 2017).

Keracunan terbagi menjadi dua hal, yaitu keracunan karena ada bahan beracun yang masuk ke dalam tubuh, yang kedua keracunan akibat mengkonsumsi makanan tertentu, lalu tubuh memberikan reaksi penolakan. Pengertian kedua ini dikenal sebagai keracunan makanan. Keracunan jenis pertama, umumnya terjadi pada anak saat tahap eksplorasi. Pada tahap ini anak sedang asyik-asyiknya mengeksplorasi lingkungan sekitarnya. Anak belum tahu banyak tentang bahaya sesuatu sehingga tanpa sadar ia memasukkan atau bahkan menelan benda mengandung racun, misalnya anak menelan kapur semut atau menggigit botol obat nyamuk. Untuk jenis keracunan yang kedua, yaitu keracunan makanan, bisa disebabkan banyak hal seperti makanan masih mentah, makanan siap saji, makanan dalam kaleng. Risiko keracunan makanan akan meningkat pada usia anak-anak, khususnya bayi dan balita. Karena mereka belum memiliki kekebalan tubuh sempurna. Orangtua harus mengenal gejala umum keracunan makanan adalah demam, kram perut, muntah-muntah, sering buang air besar, tubuh sangat lemas, menggigil, dan kehilangan nafsu makan (Dian, 2020).

Kejang Demam atau dalam istilah masyarakat awam disebut penyakit step adalah kejang pada anak yang dipicu oleh demam, bukan dikarenakan adanya kelainan di otak (willy, 2019). Kejang demam biasanya terjadi pada anak usia 6 bulan hingga 5 tahun.

\section{Tingkat Pengetahuan pada Tahap Sebelum (Pre) dan Tahap Sesudah (Post) dalam Masing-Masing Kelompok.}

Berdasarkan hasil penelitian bahwa terjadi perbedaan nilai yang bermakna untuk tingkat pengetahuan orangtua sebelum diberikan intrvensi dan sesudah diberikan intervensi. Kedua hal ini sama-sama terjadi pada responden dalam kedua kelompok. Dimana nilai tingkat pengetahuan secara signifikan mengalami perbaikan ketika dinilai setelah adanya pemberian intervensi. Hal ini selaras dengan yang disampaikan (Nursalam, 2020) bahwa pendidikan kesehatan adalah proses yang direncanakan dengan sadar untuk menciptakan peluang bagi individu-individu untuk senantiasa belajar memperbaiki kesadaran (literacy) serta meningkatkan pengetahuan dan keterampilan (life skills) demi kepentingan kesehatannya. Pendidikan kesehatan tidak hanya memberikan informasi saja, tetapi terpenting adalah menciptakan kegiatan yang dapat memandirikan seseorang untuk mengambil keputusan terhadap kesehatan yang dihadapi. 
1016 Pengaruh Model Edukasi Berbasis TIK “Aplikasi Teradam” terhadap Pengetahuan Orang Tua dalam Penatalaksanaan Kegawatdaruratan Anak - Deisy Sri Hardini, Sarwito Rachmad Barmawi DOI: https://doi.org/10.31004/basicedu.v6i1.2064

\section{Perbandingan Rerata Tingkat Pengetahuan Responden Tahap Sebelum dan Tahap Sesudah Antar Kelompok Intervensi}

Dilihat dari nilai rerata tingkat pengetahuan responden pada tahap sebelum dan tahap sesudah yang dibandingkan antar kelompok yang diberikan intervensi Aplikasi Teradam dan kelompok yang diberikan media edukasi ceramah, bahwa tidak ada perbedaan signifikan antar dua kelompok tersebut untuk tingkat pengetahuan responden. Hal ini dapat disebabkan dengan salah satu karakteristik dari responden yaitu usia orang tua dan tingkat pendidikan.

Dengan mayoritas responden yang berusia >30 tahun dan berpendidikan SD, maka berada pada tahap kedewasaan yang dikenal sebagai masa penutup pada rentang kehidupan seseorang, dimana terjadi proses perubahan menjadi menua atau lanjut usia. Pada masa dewasa akhir, kecepatan dalam memproses informasi mengalami penurunan sebagai bagian dari perkembangan kognitif.

Walaupun kecepatan pemrosesan informasi memang akan mengalami penurunan pada masa dewasa akhir, tetapi ada juga pengaruh dari faktor perbedaan individu. Beberapa komponen fungsi kognitif dewasa akhir yang mempengaruhi antara lain: Pendidikan, Pekerjaan, Kesehatan, Gagguan Kognitif Pada Dewasa Akhir, Demensia, Alzheimer, Perubahan intelektual. Dari tujuh faktor diatas, yang dapat dikaitkan dengan karakteristik responden dalam penelitian ini adalah faktor pendidikan dan faktor pekerjaan. Pada faktor pendidikan, sebagian besar responden tamatan SD, hal ini sesuai dengan teori yang menyebutkan bahwa perkembangan kognitif pada orang dewasa pun akan berjalan pesat dengan pendidikan yang tepat. Pada faktor pekerjaan bahwa karakteristik perkembangan individu pada aspek kognitif dapat menjadi masalah yang mempengaruhi. Misalnya, pada tahapan dewasa akhir, mereka sulit mengoperasikan komputer, laptop, smartphone atau gadget canggih lainnya. Sedangkan untuk generasi yang lebih muda tentunya sudah sangat akrab dengan berbagai fitur kemajuan teknologi sehingga tidak lagi mengalamai kesulitan.

\section{KESIMPULAN}

Simpulan hasil penelitian ini dirumuskan berdasarkan tujuan penelitian yang telah ditetapkan sebelumnya, yaitu sebagai berikut:

Karakteristik responden orang tua dan karakteristik anak dalam penelitian ini meliputi rerata usia orang tua 32,97 tahun, rerata usia anak 31,45 bulan, jenis kelamin anak 41 perempuan $(68,3 \%)$, kelompok usia ibu > 30 tahun sebanyak 49 orang (81,7\%), kelompok usia anak berada pada rentang 12-36 bulan sebanyak 40 orang $(66,7 \%)$, jenis kelamin orang tua semuanya adalah perempuan (100\%), dengan tingkat pendidikan SD sebanyak 25 orang $(41,7 \%)$, dan responden sebagian besar tidak bekerja sebanyak 45 orang $(75 \%)$.

Tingkat pengetahuan orang tua dalam penatalaksanaan kegawatdaruratan anak setelah diberikan intervensi adalah sebagian besar berada dalam kategori tingkat pengetahuan baik sebanyak 33 orang (55\%) Perbandingan nilai tingkat pengetahuan saat pre dan post dalam masing-masing kelompok menunjukkan perbedaan nilai yang bermakna $(\mathrm{p}<0,05)$. Perbandingan nilai tingkat pengetahuan saat pre dan post intervensi dimana perbedaan yang terjadi antar kelompok menujukkan perbedaan yang tidak bermakna ( $>0,05)$. Penggunaan Aplikasi Teradam dalam implementasi untuk tatalaksana kegawatdaruratan pada anak dapat dijadikan sebagai satu materi dalam pembelajaran Mata Kuliah Keperawatan anak dan Mata Kuliah Teknologi Informasi Keperawatan (TIK).

\section{UCAPAN TERIMAKASIH}

Terimakasih kepada LPPM Universitas Muhammadiyah Purwokerto, Dekan Fakultas Ilmu Kesehatan, Koordinator Posyandu Balita Desa Karanggintung Kecamatan Sumbang Kabupaten Banyumas Purwokerto 
1017 Pengaruh Model Edukasi Berbasis TIK “Aplikasi Teradam” terhadap Pengetahuan Orang Tua dalam Penatalaksanaan Kegawatdaruratan Anak - Deisy Sri Hardini, Sarwito Rachmad Barmawi DOI: https://doi.org/10.31004/basicedu.v6i1.2064

beserta Para Kader yang telah memberikan dukungan dan kerja sama sehingga penelitian ini dapat berjalan dengan baik dan lancar serta dapat mencapai tujuan penelitian yang sudah ditetapkan.

\section{DAFTAR PUSTAKA}

Dian, N. (2020). Pertolongan Pertama Anak Keracunan Makanan. Https://Id.Theasianparent.Com/AnakKeracunan-Makanan/

Dinkes Banyumas. (2020). Profil Kesehatan Kabupaten Banyumas Tahun 2019. Journal Of Chemical Information And Modeling.

Dream. (2017). Waspada 3 Kecelakaan Yang Sering Terjadii Pada Balita. Https://Parenting.Dream.Co.Id/Diy/Waspada-3-Kecelakaan-Yang-Sering-Terjadi-Pada-Balita170213b.Html

Evelyn, S., \& Winarti, W. (2019). Determinan Pengetahuan Bhd Dan Pertolongan Pertama Pada Guru Sekolah Dasar. Indonesian Jurnal Of Health Development.

Firken, F. (2016). Penguatan Peran Orang Tua Dalam Pendidikan Anak Melalui Pendampingan Penggunaan Teknologi Di Era Digital. Www.Kompasiana.Com

Hastono, S. . (2010). Analisis Data Kesehatan. Jakarta: Fakultas Kesehatan Masyarakat Universitas Indonesia. Jurnal Keperawatan Jiwa.

Hockenberry, M.J., W. (2014). Wong's Nursing Care Of Infant And Children (10th Ed.). Mosby: Elsevier Inc.

Hockenberry, M. J., \& David, W. (2015). Wong's Nursing Care Of Infants And Children 10th Edition. In Nursing Care Of Infants And Children.

Hockenberry, M. J., \& Wilson, D. (2015). Wong's Nursing Care Of Infants And Children. In Mycological Research.

Kementerian Kesehatan Ri. (2013). Surveilans Kesehatan Anak (Seri Balita). In Society.

Lubis, Pardizal, Hasanah Oswati, D. A. P. (2015). Gambaran Tingkat Risiko Cedera Pada Anak Usia Sekolah. Jom, 2(2). Https://Media.Neliti.Com/Media/Publications/186521-Id-None.Pdf

Luthfiyani, S. (2021). Epidemiologi Keracunan Makanan. Https://Www.Alomedika.Com/Penyakit/Gastroentero-Hepatologi/Keracunan-Makanan/Epidemiologi

Marenda, P. (2019). Fungsi Keluarga. Https://Www.Liputan6.Com/Citizen6/Read/3924338/8-FungsiKeluarga-Dan-Penjelasannya-Dari-Fungsi-Agama-Hingga-Ekonomi

Notoadmodjo. (2019). Pengantar Ilmu Perilaku Kesehatan. In Jakarta: Rineka Cipta.

Nursalam. (2020). Metodologi Penelitian Ilmu Keperawatan. In Jakarta: Salemba Merdeka.

Oktaviani, E., Feri, J., S. (2020). Pelatihan Pertolongan Pertama Kasus Kegawatdaruratan Di Sekolah Dengan Metode Simulasi. Journal Of Character Educationn Society, 3(2), 403-413.

Retno, D. (2018). Perkembangan Kognitif Pada Masa Dewasa Akhir Dan Lanjut Usia. Diakses Pada Tanggal. Https://Dosenpsikologi.Com/Perkembangan-Kognitif-Pada-Masa-Dewasa-Akhir

Riyanto, A. (2019). Aplikasi Metodologi Penelitian Kesehatan. Nuha Medika.

Sulistiana, Adila Dian Roza, N. S. (2019). Pengalaman Ibu Dalam Penanganan Tersedak Pada Bayi. AlAsalmiya Nursing, 8(2).

Alinsyirah.Ac.Id/Index.Php/Keperawatan/Article/View/176/114

Https://Jurnal.Stikes-

Sutriningsih, A., \& Ardiyani, V. M. (2018). Pengaruh Aplikasi Paediatric Triage Metode Jumpstart Terhadap Kesiapan Penanganan Awal Kegawatdaruratan Pada Anak Di Sdn Purwosari I Kabupaten Pasuruan. Care: Jurnal Ilmiah Ilmu Kesehatan. Https://Doi.Org/10.33366/Cr.V6i3.1042 
1018 Pengaruh Model Edukasi Berbasis TIK “Aplikasi Teradam” terhadap Pengetahuan Orang Tua dalam Penatalaksanaan Kegawatdaruratan Anak - Deisy Sri Hardini, Sarwito Rachmad Barmawi DOI: https://doi.org/10.31004/basicedu.v6i1.2064

Ulya. (2019). Orang Tua Kekinian Mengikuti Perkembangan Teknologi. Https://Ulyadays.Com/Orang-TuaKekinian

Utami, R. A., Setiawan, A., \& Fitriyani, P. (2019). Pengaruh Aplikasi Model "Simbol Andi" Terhadap Pengetahuan, Sikap Dan Keterampilan Anak Usia Sekolah Dengan Risiko Cedera Di Kota Depok. Jurnal Keperawatan Indonesia, 22(3), 182-190. Https://Doi.Org/10.7454/Jki.V22i3.592

Who. (2009). Buku Saku Pelayanan Kesehatan Anak Di Rumah Sakit. Pedoman Bagi Rumah Sakit Rujukan Tingkat Pertama Di Kabupaten/Kota.

Willy, T. (2019). Kejang Demam. Https://Www.Alodokter.Com/Kejang-Demam 